\title{
Dissolved organic nitrogen and nitrate in Apalachicola Bay, Florida: spatial distributions and monthly budgets
}

\author{
Behzad Mortazavi ${ }^{1, *}$, Richard L. Iverson ${ }^{1}$, Wenrui Huang ${ }^{2}$ \\ ${ }^{1}$ Department of Oceanography, Florida State University, Tallahassee, Florida 32306-4320, USA \\ ${ }^{2}$ FAMU-FSU College of Engineering, 2525 Pottsdamer St., Tallahassee, Florida 32310-6046, USA
}

\begin{abstract}
Despite the quantitative importance of dissolved organic nitrogen (DON) in aquatic systems, information on the spatial and temporal distribution of DON in estuaries is lacking. We employed a combination of property-surface plots, hydrodynamic model results, and property-salinity plots to examine nitrate and DON distributions in Apalachicola Bay, Florida, USA, during Apalachicola River high-flow and low-flow conditions. DON enters Apalachicola Bay in river water and in seawater through several passes. DON concentrations in water at some stations within the estuary exceed end-member concentrations. Therefore, DON production by phytoplankton exceeds the combined effects of dilution plus DON processing by the food web at these stations. Depending on estuarine hydrodynamics, nitrate concentrations were influenced both by dilution with low-nitrate water entering the estuary from the passes and by biological processes. In contrast to DON, nitrate concentrations declined within the estuary as salinity increased. Budget calculations indicate that DON retention within the estuary was insignificant during all months sampled. Therefore, DON that is exported from Apalachicola Bay to the Gulf of Mexico (GOM) consists of DON that enters the estuary and is not utilized in this short residence-time estuary plus a fraction produced within the estuary by the food web. Nitrate and DON exported from the estuary comprise sources of new nitrogen for the northeastern GOM food web.
\end{abstract}

KEY WORDS: Dissolved Organic Nitrogen $\cdot$ Nitrate $\cdot$ Bar-built estuary $\cdot$ Residence time

\section{INTRODUCTION}

Rivers provide the major source of nitrogen, silicate, and phosphorus, which enter the ocean from terrigenous environments. Estimates of river nitrogen, silicate, and phosphorus input to the world ocean have been made by estimating river fluxes of these elements to the sea (Froelich et al. 1982, Meybeck 1982, Tréguer et al. 1995). However, estuaries, the interface between rivers and the sea, are active sites of biogeochemical processing where nutrients are transformed before reaching the ocean. A correction factor has been applied to river concentrations to account for processing

*E-mail: mortazavi@ocean.fsu.edu of nitrogen and phosphorus within estuaries (Froelich et al. 1982, Nixon et al. 1995). While budgets have been prepared for inorganic nitrogen, silicate, and phosphorus input to the global ocean through rivers, dissolved organic matter transport from rivers into the global ocean is not as well understood (Ittekkot 1988).

Nitrogen input to near-shore marine environments is of increasing concern as the population in coastal areas increases and as instances of eutrophication are increasingly reported (Nixon 1995). Nitrogen input to estuaries occurs in particulate, inorganic, and organic forms. The particulate forms are considered less reactive, and are sequestered within the sediments after sedimentation (Pennock et al. 1999). Dissolved inorganic nitrogen (DIN) is readily utilizable by primary 


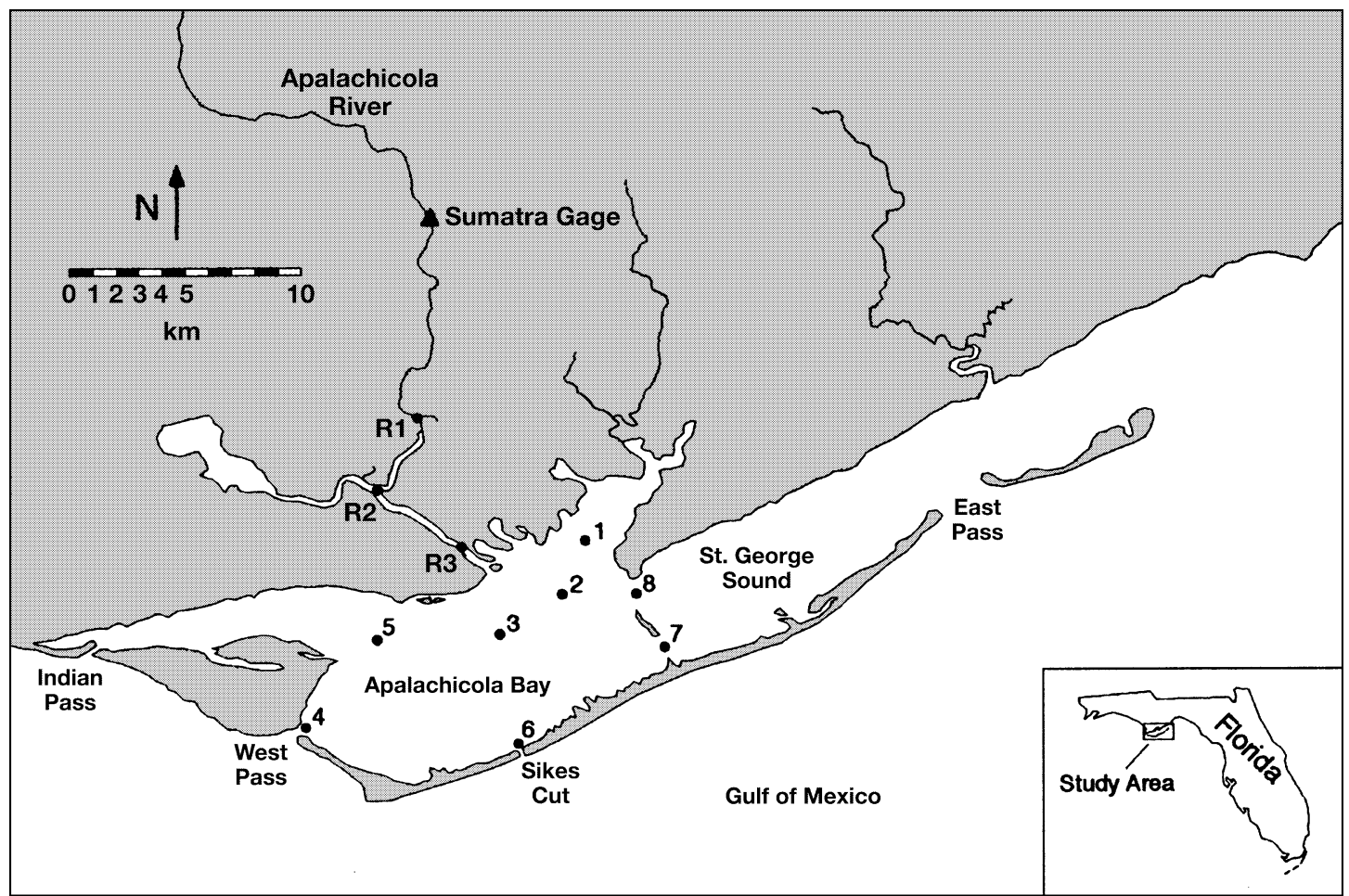

Fig. 1. Map of Apalachicola River and estuary. Apalachicola River flow was monitored at Sumatra Gage; 3 river samples (R1, R2, and R3) were sampled for nutrients; Apalachicola Bay surface and bottom samples were collected from Stns 1-8

producers, and frequently limits primary productivity in estuaries (Howarth 1988). Dissolved organic nitrogen (DON) represents a major fraction of the dissolved nitrogen pool in river water and of the nitrogen input to coastal oceans (Meybeck 1993). A fraction of riverine DON can be utilized by the estuarine bacterial community and regenerated to DIN to support phytoplankton production (Seitzinger \& Sanders 1997, Jørgensen et al. 1999), while the rest is available for export to the bordering sea (Ittekkot 1988). The preferential use of DON as a nitrogen source has been implicated in harmful algal bloom developments (Berg et al. 1997, Laroche et al. 1997).

DON in estuarine waters consists of a mixture of compounds supplied by river water and DON originating from phytoplankton and released to the water column by food-web processes (Lampert 1978, Suttle et al. 1990, Pujo-Pay et al. 1997, Hasegawa et al. 2000). A significant fraction of DIN taken up by phytoplankton is released as DON (Bronk \& Glibert 1991, Bronk \& Glibert 1993a) and can be rapidly recycled by the heterotrophic and autotrophic communities (Bronk \& Glibert 1993b). On a seasonal time scale, DON can serve as an intermediate nitrogen pool during the transition from autotrophy to heterotrophy in estuaries (Bronk et al. 1998).

The importance of DON in the dissolved nitrogen pools of river water (Meybeck 1993) and seawater
(Sharp 1983) is understood. However, information concerning the temporal and spatial distribution of DON in estuaries is limited. We coupled nitrate and DON concentration measurements with outputs from a 3dimensional numerical circulation model for Apalachicola Bay, a bar-built estuary in the northeastern Gulf of Mexico (GOM). Our objectives were (1) to report nitrate and DON spatial concentration distributions during high- and low- Apalachicola River flow conditions into Apalachicola Bay, and (2) to develop budget calculations to determine the relative importance of the passes in exchanging water, nitrate and DON with the GOM during high and low river-flow conditions.

\section{METHODS}

Field sample collection. Bar-built estuaries represent the most common morphologic features along the North American and the GOM coastline (NOAA $1997 a, b)$. On a global scale, $13 \%$ of the coastlines lie behind barrier-type spits or barrier island formations (Seibold \& Berger 1993). Our study site, Apalachicola Bay, a bar-built estuary with an area of $260 \mathrm{~km}^{2}$ and a mean depth of $2.2 \mathrm{~m}$, is situated in the northeastern GOM (Fig. 1). The estuary has a tidal range of $0.5 \mathrm{~m}$ 
and is connected to the GOM by 3 natural passes and an artificial inlet. The Apalachicola River, with the third largest flow rate in the Northern GOM (Bianchi et al. 1999), is the estuary's freshwater source. The Apalachicola River drainage basin, with an area of $44000 \mathrm{~km}^{2}$ (Fu \& Winchester 1994), is located in 3 US states. The Florida portion of the river is bordered by an extensive, forested flood plain. The average human population density $\left(11 \mathrm{~km}^{-2}\right)$ throughout the Apalachicola portion of the watershed is low (Frick et al. 1996), and is considered one of the least polluted estuaries in the US (Livingston 1984). Mean daily river flow was obtained from the US Geological Survey's gage closest to the estuary at Sumatra, Florida, located $32 \mathrm{~km}$ upstream from the river mouth.

The monthly measurements of hydrographic and chemical variables reported here were made from November 1994 through November 1995 at 3 Apalachicola River locations and 8 bay stations (Fig. 1). Surface river-water samples were collected for nitrogen analysis with a non-metallic Kemmerer water sampler. Both surface and bottom estuarine-water samples were collected for nitrate, nitrite, ammonium $\left(\mathrm{NH}_{4}{ }^{+}\right)$and DON analyses. These samples were placed in acid-washed polyethylene bottles and kept on ice in the dark for transport to the laboratory. Water for DON analyses was immediately filtered through GF/F filters (combusted at $450^{\circ} \mathrm{C}$ for $4 \mathrm{~h}$ ) and frozen for later analysis. Salinity was measured in situ with a YSI ${ }^{\circledR}$ salinometer.

Determination of chemical variables. DIN samples were analyzed within $24 \mathrm{~h}$ of sample collection. $\mathrm{NH}_{4}{ }^{+}$ was determined with the phenol-hypochlorite method as outlined in Strickland \& Parsons (1972). Nitrate $\left(\mathrm{NO}_{3}{ }^{-}\right)$concentrations were determined with the chemiluminescence detector-based method for trace nitrite $\left(\mathrm{NO}_{2}^{-}\right)$and $\mathrm{NO}_{3}^{-}$in aqueous samples. The method was developed by Cox (1980) and applied to seawater analyses by Garside (1982). We used the modified version of Garside's method (Braman \& Hendrix 1989). Nitrate and $\mathrm{NO}_{2}{ }^{-}$are rapidly reduced by vanadium (III) at 80 to $90^{\circ} \mathrm{C}$ to nitric oxide. Nitric oxide is then removed from the reaction solution by scrubbing with helium carrier gas and is detected with a Thermo Environmental ${ }^{\circledR}$ Model 42 chemiluminescence $\mathrm{NO}_{\mathrm{x}}$ analyzer. Because $\mathrm{NO}_{2}^{-}$is also reduced by this method, the procedure measures $\mathrm{NO}_{3}^{-}$plus $\mathrm{NO}_{2}^{-}$. Nitrite concentrations were measured colorimetrically (Strickland \& Parsons 1972) and subtracted from the $\mathrm{NO}_{3}{ }^{-}$plus $\mathrm{NO}_{2}{ }^{-}$values to yield $\mathrm{NO}_{3}{ }^{-}$concentrations. The $\mathrm{NO}_{3}{ }^{-}$plus $\mathrm{NO}_{2}^{-}$values determined with vanadium reduction were always higher than the $\mathrm{NO}_{2}{ }^{-}$concentrations.

Total dissolved nitrogen (TDN) concentrations were determined with the persulfate oxidation method. Briefly, $2.5 \mathrm{ml}$ of a potassium persulfate oxidizing reagent (Pujo-Pay \& Raimbault 1994) was added to $20 \mathrm{ml}$ of filtered seawater and autoclaved at $120^{\circ} \mathrm{C}$ for $0.5 \mathrm{~h}$. The digestions were carried out in acid-washed $(10 \% \mathrm{HCl})$ Teflon bottles with screw caps. After cooling to room temperature nitrate was determined as described above. DON concentrations were determined by subtracting DIN from TDN concentrations.

Water export and residence-time calculations. Water export from the estuary to the GOM was determined with a 3-dimensional, time-dependent, numerical hydrodynamic model, which allowed velocity, temperature and salinity field calculations (Huang \& Jones 1997). A Blumberg \& Mellor $(1980,1987)$ model application to Apalachicola Bay used an explicit-in-horizontal, implicitin-vertical, finite-difference format with freshwater inflow, tide, and wind-stress forcing. The model has been previously applied to Apalachicola Bay (Jones et al. 1994, Jones \& Huang 1996) as well as to other estuaries such as Chesapeake Bay (Blumberg \& Goodrich 1990) and Delaware Bay (Galperin \& Mellor 1990). The set of governing equations is given by Blumberg \& Herring (1987). The model solved a coupled system of prognostic differential equations describing conservation of mass, momentum, heat, and salinity at each of 930 horizontal grids and 5 vertical layers of the computational scheme. A horizontal, orthogonal, curvilinear coordinate system allowed representation of coastline irregularities. A sigma coordinate system allowed vertical stretching to simulate water-level changes in the estuary. A turbulence closure sub-model (Mellor \& Yamada 1982, Galperin et al. 1988), which provides eddy viscosity and eddy diffusivity for vertical mixing, permitted variation in the forcing factors (Huang \& Jones 1997).

The model was calibrated and verified with hydrographic data recorded at $0.5 \mathrm{~h}$ intervals from in situ instruments located throughout the estuary during a 6 mo period (Huang \& Jones 1997). For simulations used in the present analysis, measured river discharge, winds, tides, temperature, and salinity were applied to the model as boundary conditions. The model was used to calculate water inflow and export at the passes. The estuarine-water residence time was calculated by dividing the estuary's volume by the sum of the total water imported into the estuary.

River-nutrient input was determined by multiplying average river-nutrient concentration by mean river flow for the $5 \mathrm{~d}$ prior to sampling. Nutrient exchange at the passes was determined by multiplying average surface and bottom nutrient concentrations at each pass by mean water exchange for the $5 \mathrm{~d}$ prior to sampling. Because only 2 samples were collected at West Pass, Indian Pass, and Bob Sikes Cut, the relative standard error at St. George Sound $(n=4)$ was applied to these passes. Error propagation, including the stan- 

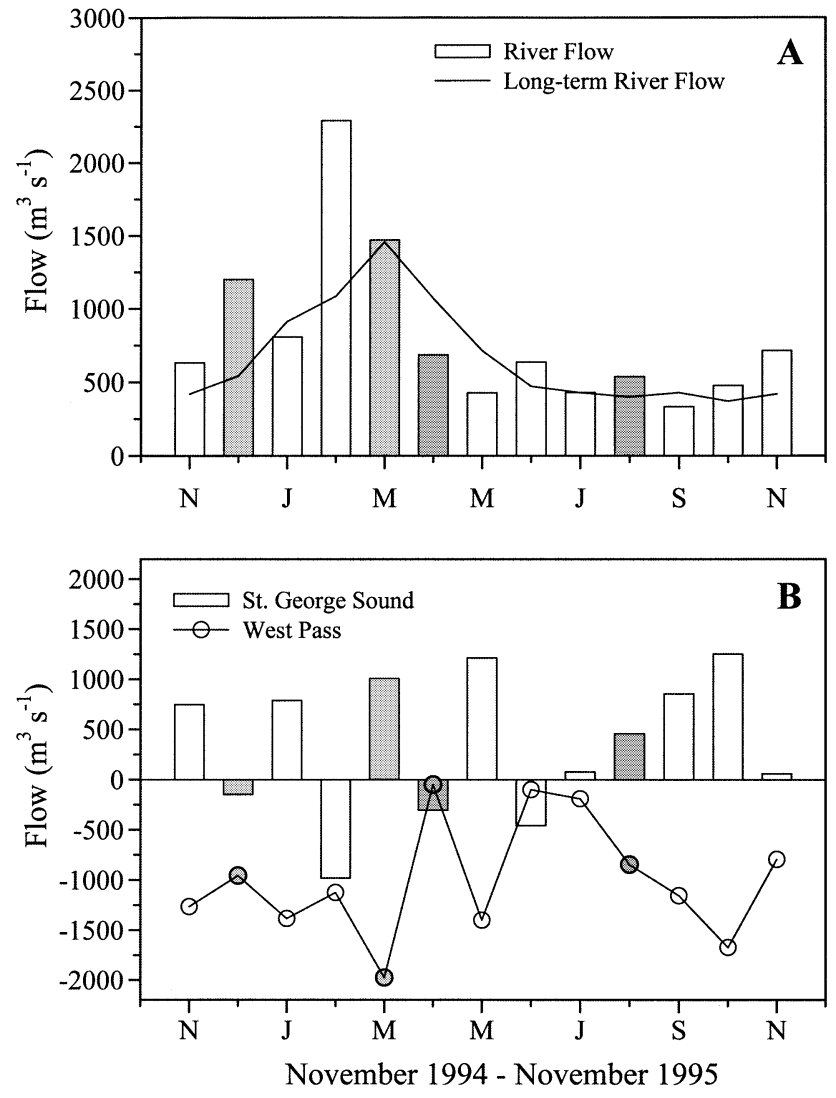

Fig. 2. (A) Apalachicola River discharge, long-term (1965 to 1989) monthly mean and discharge 5 d prior to sampling; shaded bars: months examined in this study. (B) Water exchange at St. George Sound and at West Pass averaged for $5 \mathrm{~d}$ prior to sampling; shaded bars and circles: months examined in this study

dard error for the river and passes, was applied to estimates of nutrient input to the estuary and export to the GOM for each month.

\section{RESULTS}

\section{Hydrology}

Apalachicola River discharge minima occur during the summer season, while the winter and early spring seasons are characterized by discharge maxima (Fig. 2A) in response to rainfall over the river drainage basin. Mean river discharge for the study period (November 1994 to November 1995) was $819 \mathrm{~m}^{3} \mathrm{~s}^{-1}$, slightly exceeding the long-term (1965 to 1989) Apalachicola River monthly mean discharge $\left(710 \mathrm{~m}^{3} \mathrm{~s}^{-1}\right)$ (Fu \& Winchester 1994).

St. George Sound (Fig. 1) was the major source of GOM water to the estuary. Mean $( \pm 1 \mathrm{SE})$ seawater input to the estuary for the study period was $505 \pm$
$136 \mathrm{~m}^{3} \mathrm{~s}^{-1}$. St. George Sound accounted for all the seawater input to the estuary, except in June 1995 when Indian Pass contributed $81 \mathrm{~m}^{3} \mathrm{~s}^{-1}$ of GOM water to the estuary. GOM water-inflow minima to the estuary occurred during high river-flow periods, except in March 1994 when there was a significant water inflow from the GOM concurrent with high river discharge (Fig. 2). GOM water-inflow maxima to the estuary occurred in low river-flow periods such as May $\left(1212 \mathrm{~m}^{3}\right.$ $\mathrm{s}^{-1}$ ) and October (1253 $\left.\mathrm{m}^{3} \mathrm{~s}^{-1}\right) 1995$ and exceeded the long-term mean river flow for those months by 1.7 and 3.4 times, respectively (Fig. 2). On average, $69 \%$ of the water outflow from the estuary to the GOM occurred through West Pass (Fig. 1). However, in April and June 1995, St. George Sound was the major water outlet for the estuary and accounted for 66 and $76 \%$ of the total water outflow to the GOM, respectively.

\section{Salinity, DIN, and DON distributions during river high-flow periods}

In December 1994, freshwater input to the estuary from the Apalachicola River exceeded the long-term mean river flow into the estuary by a factor of 3 (Fig. 2A). Seawater input from the passes to the estuary was insignificant during this month (Fig. 2B). The average estuarine salinity in December 1995 was $13.5 \pm 1.6 \mathrm{psu}$. The greater fraction of the total water export to the GOM occurred through West Pass at a salinity of $16.5 \mathrm{psu}$ (Fig. 3A).

Average Apalachicola River nitrate concentration in December 1994 was $252.5 \pm 2.2 \mu \mathrm{g} \mathrm{N} \mathrm{^{-1 }}$. Nitrate concentration in the estuary averaged $138.5 \pm 14.5$ and decreased with increasing salinity from the river mouth to reach minimal concentrations near the estuaryGOM boundary (Figs. 3B, 4A). Nitrate concentration at West Pass and St. George Sound were 127.0 (range: 123.4 to 130.7 ) and $72.5 \pm 3.3 \mu \mathrm{g} \mathrm{N} \mathrm{l}^{-1}$, respectively.

In December 1994, the mean Apalachicola River DON concentration $\left(201.6 \pm 17.0 \mu \mathrm{g} \mathrm{N}^{-1}\right)$ was similar to DON concentration exported from the estuary at St. George Sound $\left(181.9 \pm 6.2 \mu \mathrm{g} \mathrm{N}^{-1}\right)$ and water exiting the estuary at West Pass (Fig. 4B). In contrast to nitrate concentrations that decreased with increasing distance from the river mouth, DON concentration maxima were observed at mid-salinity ranges in the estuary (Figs. 3C, 4B).

In March 1995, Apalachicola River flow had reached $1471 \mathrm{~m}^{3} \mathrm{~s}^{-1}$, a typical flow rate for this month (Fig. 2A). In contrast to December 1994, however, there was significant seawater input to the estuary from the GOM (Fig. 5A). The March 1995 mean estuarine salinity was $8.7 \pm 2.0 \mathrm{psu}$. Water exported at West Pass at a salinity of 5.2 psu accounted for $82 \%$ of the total water 

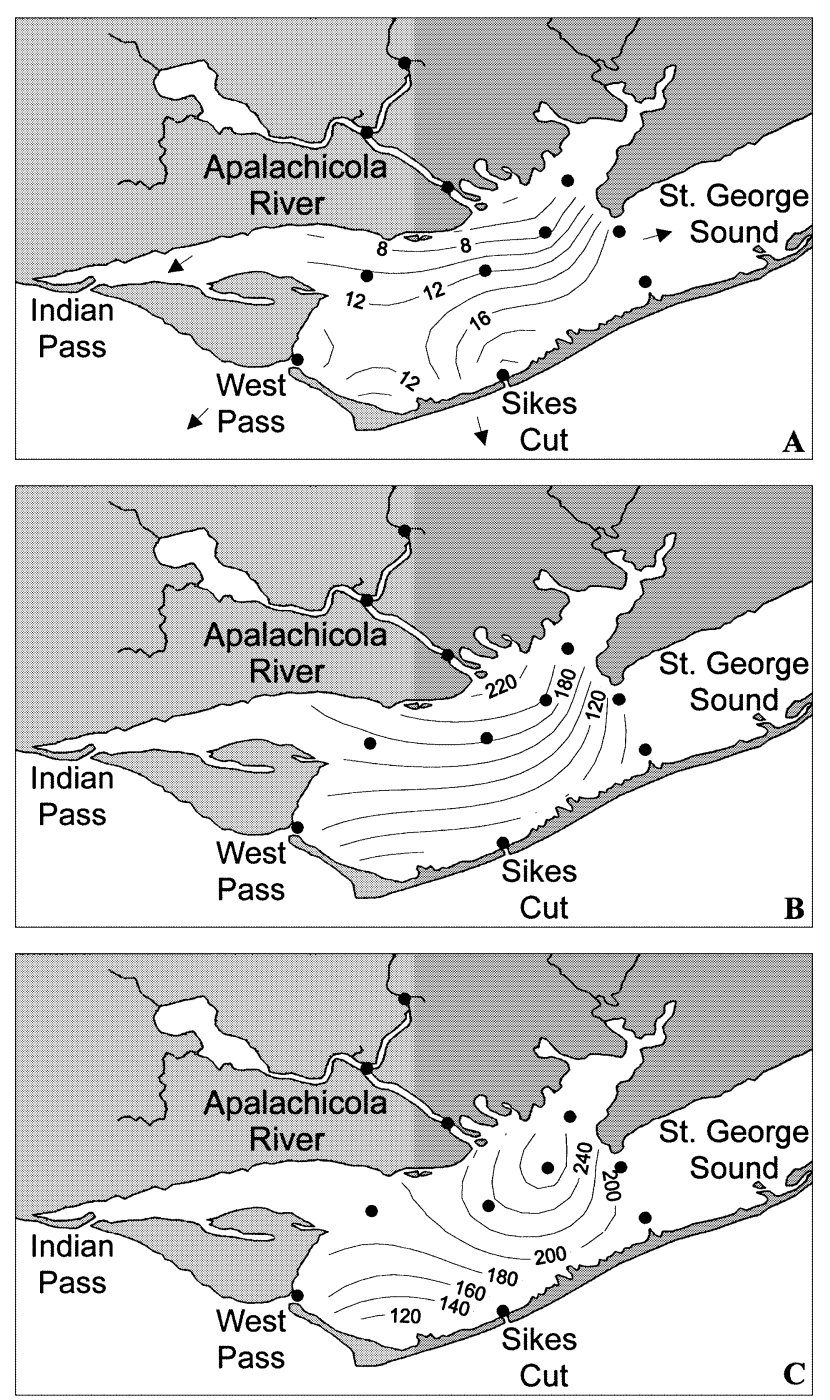

Fig. 3. Apalachicola Bay, December 1994. (A) Contour plots of mean salinity, psu (arrows indicate direction of water exchange at passes), (B) mean surface and bottom nitrate concentration $\left(\mu \mathrm{g} \mathrm{N}^{-1}\right),(\mathrm{C})$ mean surface and bottom DON concentration $\left(\mu \mathrm{g} \mathrm{N}^{-1}\right)$

exported to the GOM, while $13 \%$ of the total water exported to the GOM was exported through Indian Pass at 2 psu (Fig. 5A).

In March 1995, the average Apalachicola River nitrate concentration $\left(388.7 \pm 5.5 \mu \mathrm{g} \mathrm{N} \mathrm{l}^{-1}\right)$ exceeded the mean estuarine nitrate concentration $(228.4 \pm$ $30.3 \mu \mathrm{g} \mathrm{N} \mathrm{l}^{-1}$ ) (Fig. 6A). Nitrate concentrations decreased with increasing salinity within the estuary (Fig. 5B), reaching minimal values at the boundary with St. George Sound $\left(61.8 \pm 4.5 \mu \mathrm{g} \mathrm{N}^{-1}\right)$ (Fig. 6A). The mean DON concentration at the St. George Sound boundary $\left(156.8 \pm 34.3 \mu \mathrm{g} \mathrm{N} \mathrm{l}^{-1}\right)$ was similar in magnitude to river DON concentrations (Fig. 6B). In a fashion similar to the DON distribution in December 1994,
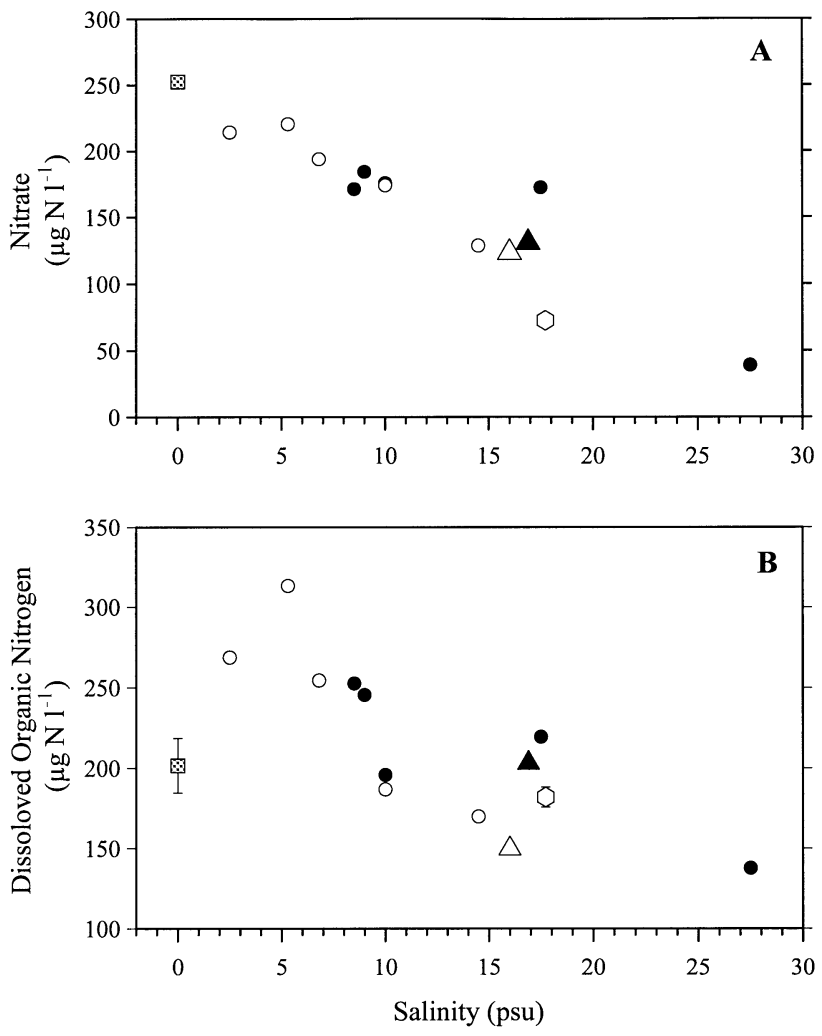

Fig. 4. Apalachicola River, December 1994, river and estuary nitrate $(\mathrm{A})$ and DON (B) versus salinity. $($ ( $)$ river; $(0, \mathbf{0})$ surface and bottom samples respectively; $(\triangle, \mathbf{\Lambda})$ surface and bottom West Pass samples respectively; $(\bigcirc)$ mean concentration at St. George Sound; error bars in (B): $\pm 1 \mathrm{SE}_{\text {; }}$ error bars for river and St. George Sound nitrate smaller than symbols

DON concentrations increased from $130.7 \pm 6.5 \mu \mathrm{g} \mathrm{N}^{-1}$ in the river to reach maxima at low salinity ranges in the estuary during March 1995 (Figs. 5C, 6B). Water exported at West Pass had a DON concentration of $145.2 \mathrm{\mu g} \mathrm{N}^{-1}$ (Fig. 6B).

\section{Salinity, DIN, and DON distributions during river low-flow periods}

The April 1995 Apalachicola River discharge $\left(685 \mathrm{~m}^{3}\right.$ $\mathrm{s}^{-1}$ ) was lower than the long-term river flow for that month (Fig. 2A). Mean Apalachicola Bay salinity in April 1995 was $16.0 \pm 1.7 \mathrm{psu}$. During this month, water was exported to the GOM at all passes, with $66 \%$ exported through St. George Sound at 18 psu (Fig. 7A). Mean Apalachicola River nitrate and DON concentrations in April 1995 were $449.8 \pm 17.5 \mu \mathrm{g} \mathrm{N} \mathrm{l}^{-1}$ and $199.2 \pm 5.2 \mu \mathrm{g} \mathrm{N} \mathrm{l}^{-1}$, respectively (Fig. 8A,B). Mean nitrate concentration in the estuary $(102.5 \pm 22.2 \mu \mathrm{g}$ $\mathrm{N} \mathrm{l}^{-1}$ ) was approximately 4 times lower than mean 

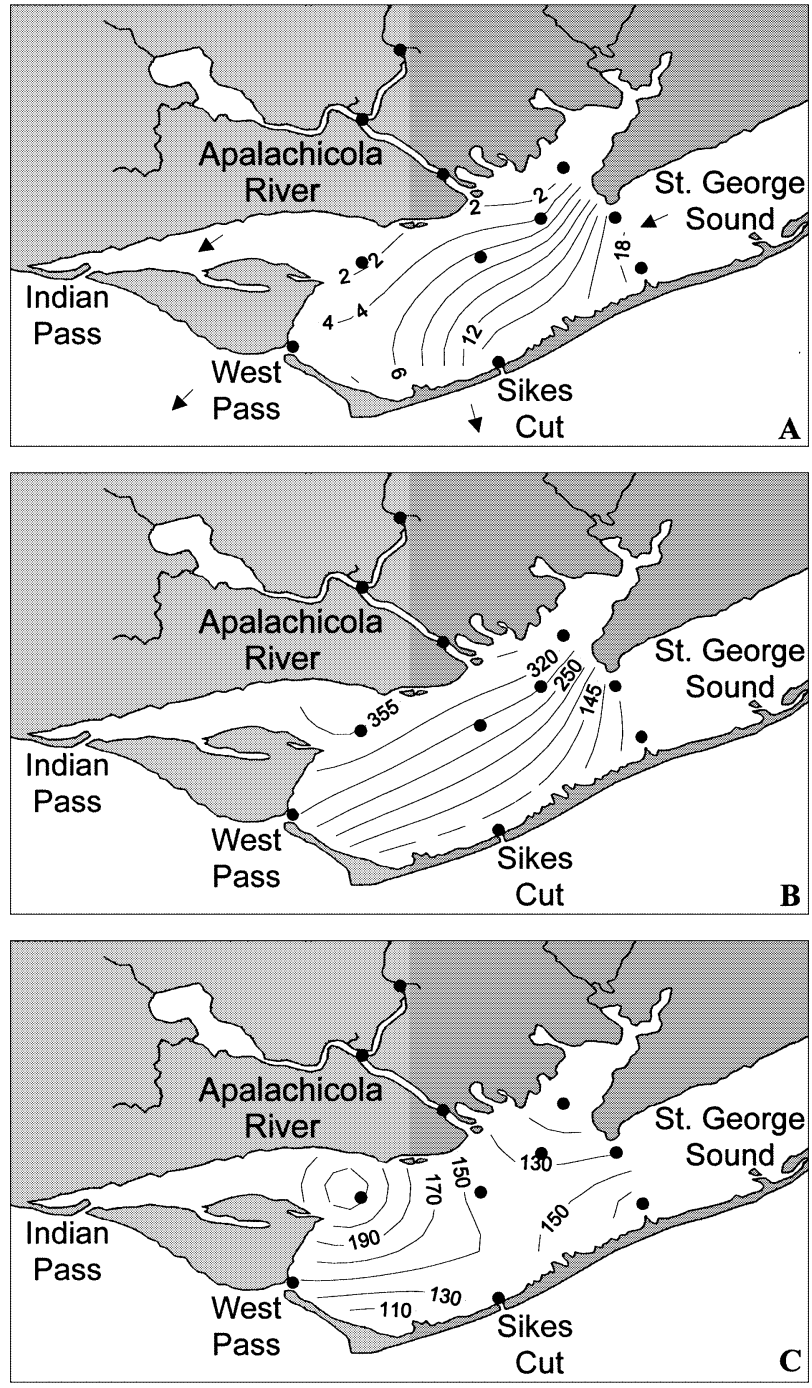

Fig. 5. Apalachicola Bay, March 1995. Contour plots of (A) mean salinity (arrows indicate the direction of water exchange at the passes), (B) mean surface and bottom nitrate concentration $\left(\mu \mathrm{g} \mathrm{N}^{-1}\right)$, (C) mean surface and bottom DON concentration $\left(\mathrm{\mu g} \mathrm{N} \mathrm{I}^{-1}\right)$

river DON concentration. Average estuarine DON concentration $(183.7 \pm 7.2)$ was similar to river DON concentration. In contrast to nitrate concentrations, which decreased with increasing distance from the river mouth (Figs. 7B, 8A), DON concentration maxima were observed at mid-salinity ranges (Figs. $7 \mathrm{C}$, 8B).

In August 1995, freshwater input from the Apalachicola River was similar in magnitude to the longterm mean river flow (Fig. 2A). There was significant water inflow from the GOM through the passes during August, 1995 (Fig. 2B), when the average salinity in the estuary was $17.6 \pm 1.5 \mathrm{psu}$. Eighty-five percent of water exported from the estuary was through West
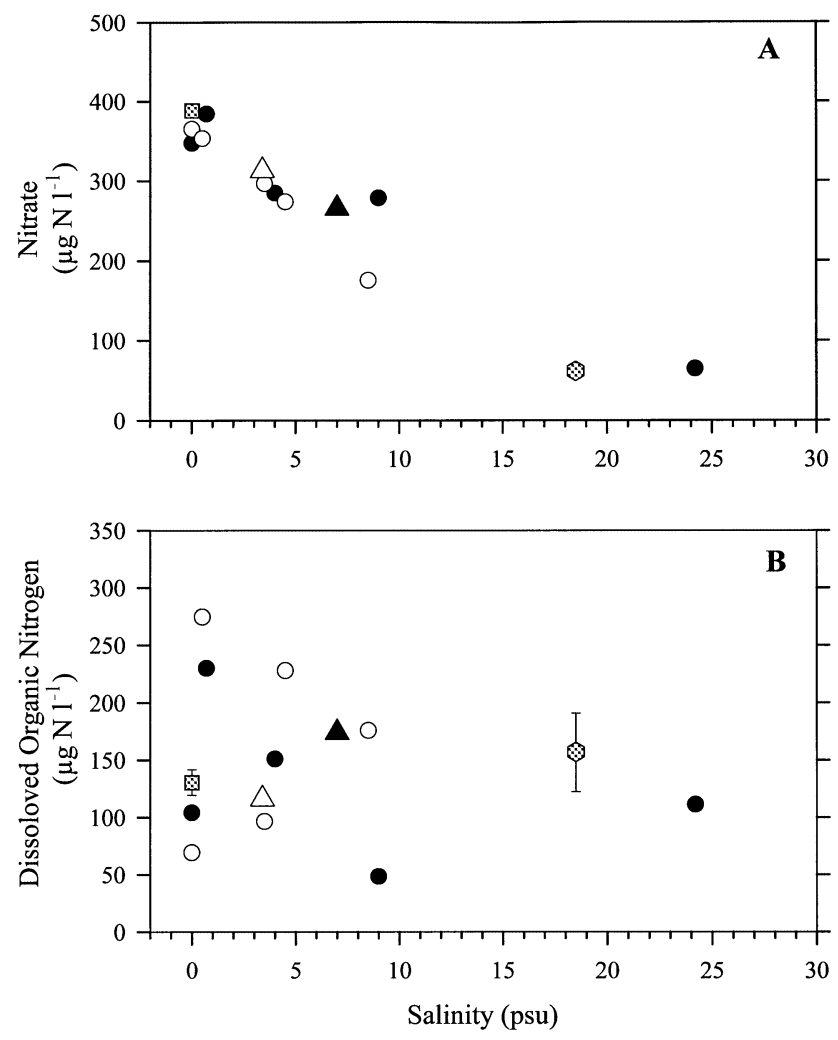

Fig. 6. Apalachicola River, March 1995, river and estuary nitrate (A) and DON (B) versus salinity. ( $(\mathbf{0})$ river; $(0,0)$ surface and bottom samples respectively; $\left(\Delta_{,} \mathbf{\Lambda}\right)$ surface and bottom West Pass samples respectively; (ㅇ) mean concentration at St. George Sound which was a source of water to the estuary during this month; error bars in $(\mathrm{B}): \pm 1 \mathrm{SE}_{\text {; }}$ error bars for river and St. George Sound nitrate smaller than symbols

Pass at a salinity of $24 \mathrm{psu}$, while $12 \%$ of water exported from the estuary was through Indian Pass at 14 psu (Fig. 9A).

In August 1995, average Apalachicola River nitrate concentration was $188.6 \pm 0.9 \mu \mathrm{g} \mathrm{N} \mathrm{m}{ }^{-3}$ decreasing to $<1 \mu \mathrm{g} \mathrm{N}^{-1}$ in the estuary (Figs. 9B, 10A). In contrast to the rapid decline in nitrate concentration from the mouth of the river to the estuary-GOM boundary, DON concentrations increased from the average river con-

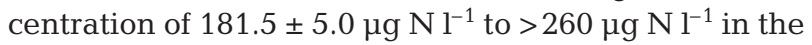
estuary at mid-salinity ranges (Figs. 9C, 10B).

\section{Monthly budget calculations}

Apalachicola Bay exchanges water with the GOM through 4 passes, depending on the prevailing winds and tides (Fig. 1). Therefore, each pass could act as a sink or source for the nitrate, complicating the interpretation of property-salinity plots. 

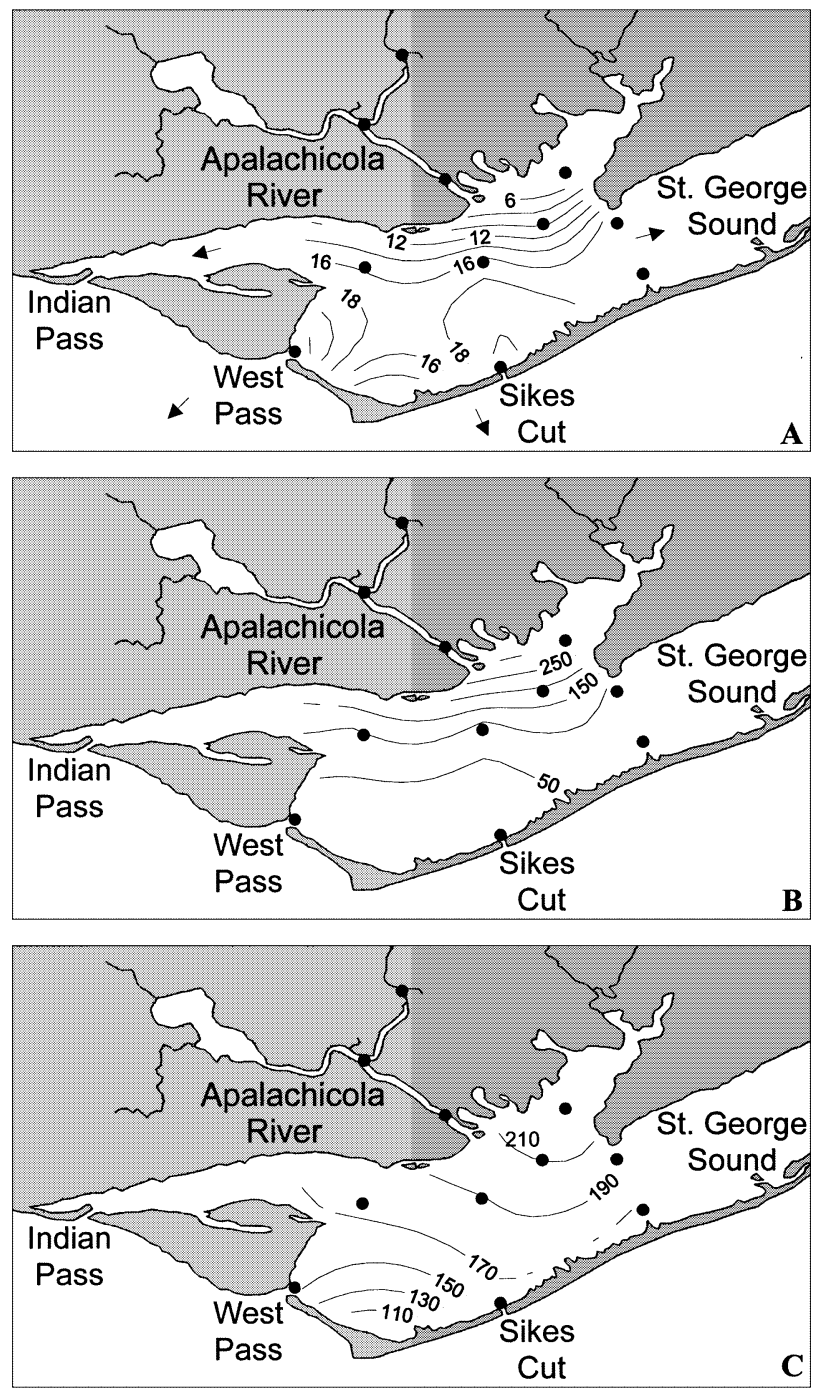

Fig. 7. Apalachicola Bay, April, 1995. Contour plots of (A) mean salinity, psu (arrows indicate the direction of water exchange at the passes); (B) mean surface and bottom nitrate concentration ( $\mu \mathrm{g} \mathrm{N}^{-1}$ ); (C) mean surface and bottom DON concentration $\left(\mu \mathrm{g} \mathrm{N} \mathrm{l}^{-1}\right)$

In December 1994, water was exported from the estuary to the GOM through West Pass at a flow rate of $957 \mathrm{~m}^{3} \mathrm{~s}^{-1}$, while a smaller fraction was exported at the other passes (Fig. 3A). Nitrate retention within the estuary is not apparent from examination of Fig. 3B or Fig. 4A. However, nitrate budget calculations indicate that there was a net nitrate retention of $13.1 \pm 2.8 \mathrm{t} \mathrm{N}$ $\mathrm{d}^{-1}$ within the estuary, while a similar amount was exported to the GOM during December 1994 (Table 1).

In December 1994, Apalachicola River DON input to the estuary $\left(20.9 \pm 1.7 \mathrm{t} \mathrm{N} \mathrm{d}^{-1}\right)$ was similar in magnitude to river nitrate input (Table 2). Examination of the surface plot suggests that DON was exported through all the passes during this month (Fig. 3C). The budget
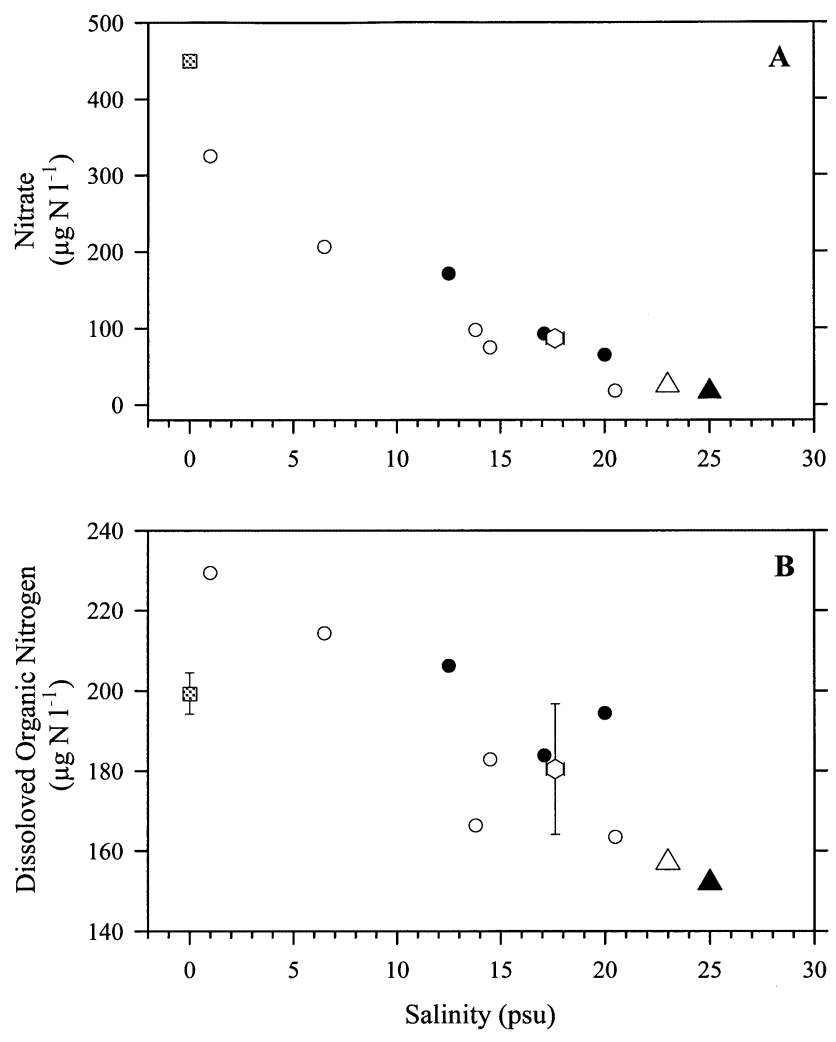

Fig. 8. Apalachicola River, April 1995, river and estuary nitrate (A) and DON (B) versus salinity. $(O, \bullet)$ surface and bottom samples respectively; $(\mathbf{Q})$ river; $(\triangle, \mathbf{\Delta})$ surface and bottom West Pass samples respectively; $(\bigcirc)$ mean concentration at St. George Sound; error bars in (B): $\pm 1 \mathrm{SE}$; error bars for river and St. George Sound nitrate smaller than symbols

calculation results indicated that DON retention within the estuary $\left(1.7 \pm 1.9 \mathrm{t} \mathrm{N} \mathrm{d}^{-1}\right)$ was insignificant for December 1994 (Table 2).

Apalachicola River flow in March 1995 had typical late-winter and early-spring values (Fig. 2A), with significant seawater inflow to the estuary from the GOM (Fig. 2B). This resulted in a very short freshwater residence-time of 2.8 d. During March 1995, nitrate input from the passes accounted for $12 \%$ of the total nitrate input to the estuary (Table 1). Budget calculations for March 1995 suggest that nitrate export to the GOM $\left(60.7 \pm 4.4 \mathrm{t} \mathrm{N} \mathrm{d}^{-1}\right)$ and input to the estuary (54.6 $\pm 0.8 \mathrm{t}$ $\mathrm{N} \mathrm{d}^{-1}$ ) were approximately balanced (Table 1). Despite the high level of nutrient input to the estuary, low salinity water (Fig. 5A) with high nitrate concentrations (Figs. 5B \& 6A) was relatively rapidly flushed out of the estuary. Apalachicola River DON input to the estuary $\left(16.6 \pm 0.8 \mathrm{t} \mathrm{N} \mathrm{d}^{-1}\right)$ in March 1995 was equivalent to DON input from the passes $\left(13.7 \pm 3.0 \mathrm{t} \mathrm{N} \mathrm{d}^{-1}\right)$. DON was exported from Apalachicola Bay at a rate of $33.1 \pm 7.2 \mathrm{t} \mathrm{N} \mathrm{d}^{-1}$, similar to the input rate (Table 2). 

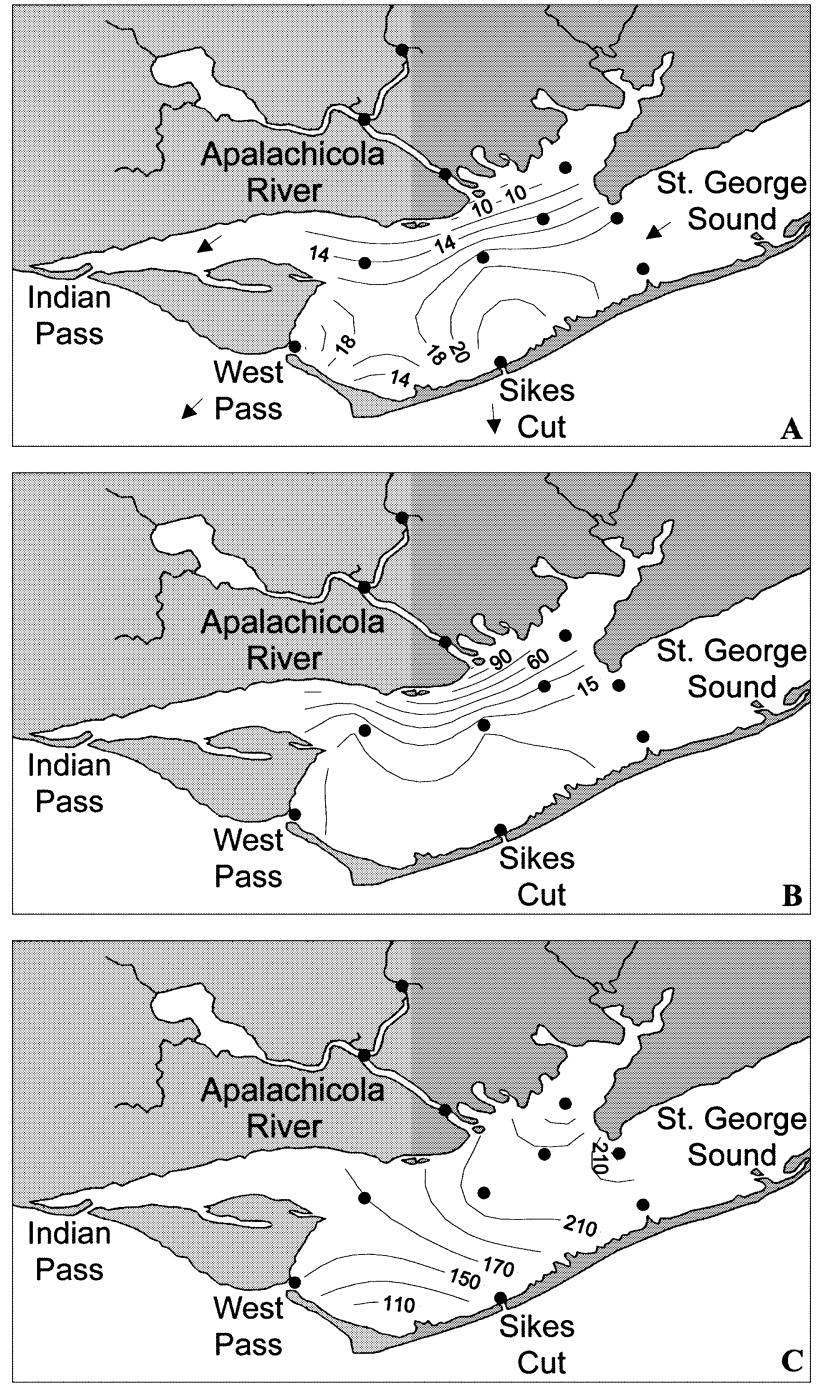

Fig. 9. Apalachicola Bay, August 1995. Contour plots of (A) mean salinity (arrows indicate the direction of water exchange at the passes); (B) mean surface and bottom nitrate concentration ( $\mu \mathrm{g} \mathrm{N}^{-1}$ ); (C) mean surface and bottom DON concentration $\left(\mu \mathrm{g} \mathrm{N} \mathrm{l}^{-1}\right)$

During April 1995, the Apalachicola River accounted for the entire nitrate input to the estuary (Table 1). The estuarine residence-time during this period was $9.6 \mathrm{~d}$. Approximately $25 \%$ of nitrate input to the estuary was exported to the GOM at a rate equivalent to $3.0 \pm 0.2 \mathrm{t}$ $\mathrm{N} \mathrm{d}^{-1}$, while $9.2 \pm 0.5 \mathrm{t} \mathrm{N} \mathrm{d}^{-1}$ was retained in the estuary. DON export $\left(7.0 \pm 0.5 \mathrm{t} \mathrm{N} \mathrm{d}^{-1}\right)$ from the estuary to the GOM (Table 2) exceeded nitrate export during this month (Table 1).

In August 1995, despite approximately equal seawater and freshwater inflow to the estuary, Apalachicola River accounted for $89 \%$ of the nitrate input to the estuary (Table 1). During this month, the water residence-time had reached $6.6 \mathrm{~d}$ and nitrate was rapidly removed within the estuary, as indicated both in the nitrate surface plot (Fig. 9B) and the nitrate-salinity (Fig. 10A) plots. The budget calculations suggest that nitrate was retained in the estuary at a rate equivalent to $8.7 \pm 0.2 \mathrm{t} \mathrm{N} \mathrm{d}^{-1}$ (Table 1 ).

In August 1995, DON input through the passes accounted for $49 \%$ of the total DON input to the estuary. Budget calculations for this month indicated that DON retention within the estuary was insignificant $(3.4 \pm 2.7$ $\mathrm{t} \mathrm{N} \mathrm{d}^{-1}$ ), with most of DON input to the estuary being exported to the GOM $\left(13.3 \pm 2.5 \mathrm{t} \mathrm{N} \mathrm{d}^{-1}\right)$ (Table 2).

\section{DISCUSSION}

\section{Hydrodynamics and nitrate and DON input to Apalachicola Bay}

The general hydrodynamic circulation pattern in Apalachicola Bay is from the east to the west (Huang \& Jones 1997). However, the magnitude and direction of
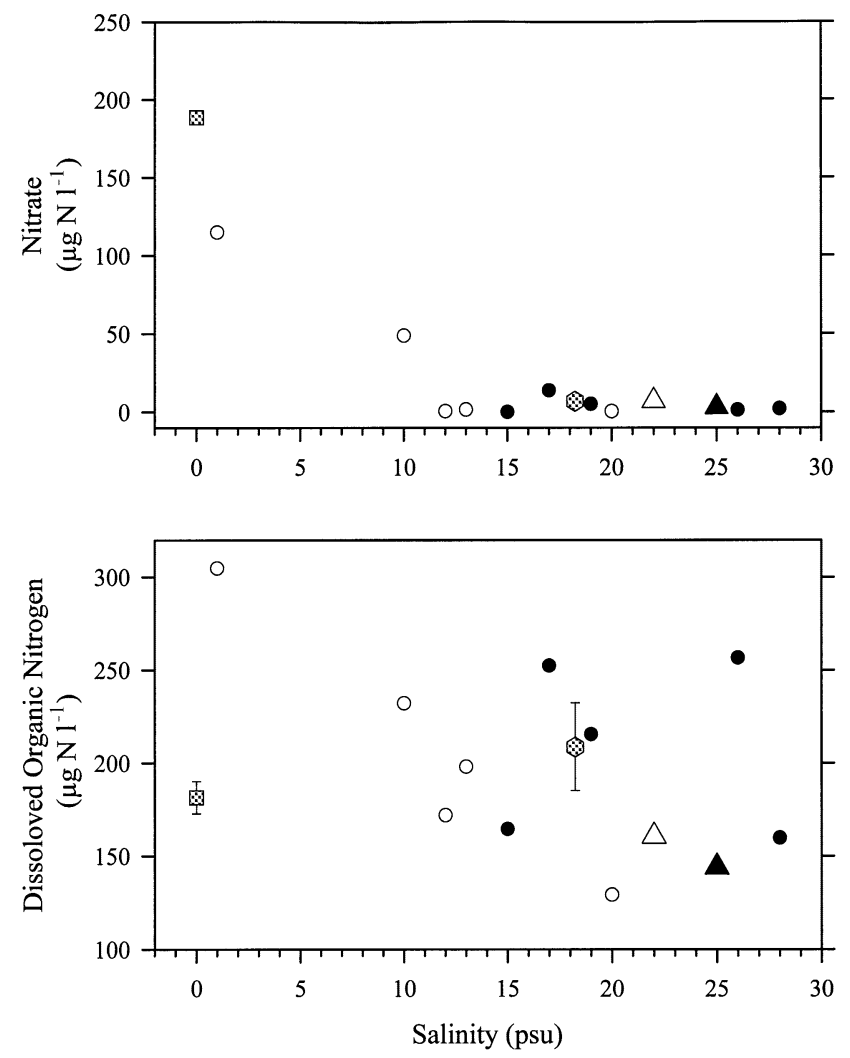

Fig. 10. Apalachicola River, August 1995, river and estuary nitrate (A) and DON (B) versus salinity; ( face and bottom samples respectively; $(\Delta, \boldsymbol{\Lambda})$ surface and bottom West Pass samples respectively; ( $)$ mean concentration at St. George Sound, which was a source of water to the estuary;rror bars in (B): $\pm 1 \mathrm{SE}$; error bars for river and St. George Sound nitrate smaller than symbols 
Table 1. Nitrate input ( $\mathrm{N} \mathrm{d}^{-1} \pm 1 \mathrm{SE}$ ) to Apalachicola Bay in December 1994 and March, April and August 1995. On average, nitrate represented $76 \%$ of DIN exported during these 4 mo. Annual budget for period November 1994 to November 1995 (from Mortazavi et al. 2000a) is also shown. GOM: Gulf of Mexico

\begin{tabular}{|lccrc|}
\hline Month & $\begin{array}{c}\text { River input } \\
(1)\end{array}$ & $\begin{array}{c}\text { Input from passes } \\
(2)\end{array}$ & $\begin{array}{c}\text { Export to GOM } \\
(3)\end{array}$ & $\begin{array}{c}\text { Retained } \\
(1+2)-(3)\end{array}$ \\
\hline December 1994 & $26.3 \pm 2.8$ & 0 & $13.2 \pm 0.6$ & $13.1 \pm 2.8$ \\
March 1995 & $49.4 \pm 0.7$ & $5.2 \pm 0.4$ & $60.7 \pm 4.4$ & $-6.1 \pm 4.5$ \\
April 1995 & $12.1 \pm 0.5$ & 0 & $3.0 \pm 0.2$ & $9.1 \pm 0.5$ \\
August 1995 & $8.8 \pm 0.1$ & $0.3 \pm 0.1$ & $0.4 \pm 0.2$ & $8.7 \pm 0.2$ \\
Annual DIN budget & $27.0 \pm 0.1$ & $2.3 \pm 0.2$ & $19.5 \pm 1.2$ & $9.8 \pm 1.7$ \\
\hline
\end{tabular}

water flow at the passes is variable (Fig. 2B) and depends on tidal current velocity and wind direction. During the river high- and low-flow months, St. George Sound acted either as an outlet (December 1994, April 1995) or as a significant source of water to the estuary (March and August 1995). Therefore, depending on water circulation patterns in the estuary, St. George Sound was a nitrogen source or sink for the estuary (Tables 1 \& 2).

Under ordinary circumstances, GOM water enters St. George Sound from the east and is transported through the Sound into Apalachicola Bay. However, with a northwesterly wind, Apalachicola River water can exit the estuary into St. George Sound, remain within the Sound, and then again enter the estuary upon wind relaxation. This oscillation effect is apparent in the numerical simulation-model results of Huang \& Jones (1997).

Nitrate accounts for $97 \%$ of the Apalachicola River DIN input to the estuary (Mortazavi et al. 2000b). During periods when St. George Sound was a water source for the estuary, St. George Sound nitrate input to the estuary was minor compared to Apalachicola River nitrate input (Table 1). In contrast, DON input rate through St. George Sound was approximately similar in magnitude to the Apalachicola River DON input rate to the estuary during 2 of 4 mo reported here (Table 2). On an annual time scale, however, the Apalachicola River is the main nitrogen source to the estuary, accounting for $92 \%$ of the total DIN input and $71 \%$ of the total DON input to the estuary (Mortazavi et al. 2000a).

\section{Nitrate and DON concentrations related to salinity}

Property-salinity plots have been used for determining element reactivity within estuaries (Boyle et al. 1974) and to infer the reactivity of dissolved organic matter (DOM) in coastal environments (Gardner \& Stephens 1978, Mantoura \& Woodward 1983). These plots have been used to construct nutrient budgets for Ocklockonee Bay (Kaul \& Froelich 1984) and for the Ems estuary (van Beusekom \& de Jonge 1998).

There are, however, limitations in the application of property-salinity plots to estuarine data. Officer (1979) showed that applications of these plots for use in quantitative calculations might not be appropriate in systems with complex hydrodynamics. Property-salinity plots are applicable to systems with 2 end-members, where the temporal variations in concentration of the constituent are less than the hydrodynamic residencetime of the estuary (Loder \& Reichard 1981, Officer \& Lynch 1981). A steady-state hydrodynamic condition must be assumed, which implies that the observed variations in the concentration of a constituent are governed only by biogeochemical processes (Regnier et al. 1998). The effective river concentration, which indi-

Table 2. DON input ( $\mathrm{N} \mathrm{d}^{-1} \pm 1 \mathrm{SE}$ ) to Apalachicola Bay in December 1994 and March, April and August 1995. Annual budget for period November 1994 to November 1995 (from Mortazavi et al. 2000a) is also shown

\begin{tabular}{|lccrr|}
\hline Month & $\begin{array}{c}\text { River input } \\
(1)\end{array}$ & $\begin{array}{c}\text { Input from passes } \\
(2)\end{array}$ & $\begin{array}{c}\text { Export to GOM } \\
(3)\end{array}$ & $\begin{array}{c}\text { Retained } \\
(1+2)-(3)\end{array}$ \\
\hline December 1994 & $20.9 \pm 1.7$ & 0 & $19.2 \pm 0.7$ & $1.7 \pm 1.9$ \\
March 1995 & $16.6 \pm 0.8$ & $13.7 \pm 3.0$ & $33.1 \pm 7.2$ & $-2.8 \pm 7.9$ \\
April 1995 & $5.4 \pm 0.1$ & 0 & $7.0 \pm 0.5$ & $-1.6 \pm 0.5$ \\
August 1995 & $8.4 \pm 0.9$ & $8.3 \pm 0.9$ & $13.3 \pm 2.5$ & $3.4 \pm 2.7$ \\
Annual DON budget & $17.4 \pm 1.6$ & $6.5 \pm 0.5$ & $23.4 \pm 1.8$ & $0.5 \pm 2.5$ \\
\hline
\end{tabular}


cates the reactivity of an element in an estuary (Wen et al. 1999), is estimated by extrapolation from high-salinity concentrations to zero salinity. However, during times when there is a limited salinity range, this procedure can lead to a $\pm 50 \%$ uncertainty at the $95 \%$ confidence interval (Yeats 1993). A bar-built, or barrier island estuary may exchange water and nutrients at more than 1 location if it has more than 1 opening to the sea. Therefore, application of property-salinity plots to data acquired from bar-built estuaries as a quantitative tool for estimating nutrient retention and export may violate the conditions defined by Officer \& Lynch (1981). Despite these limitations, property-salinity plots are useful heuristic tools with which to draw inferences about nutrient distribution patterns in barbuilt estuaries with multiple open passes.

The nitrate-salinity plots for Apalachicola Bay show the general patterns observed in tropical (Eyre \& Balls 1999) and temperate-latitude (Pennock et al. 1999) coastal lagoons, with nitrate decreasing as salinity increases along a gradient through the estuary. However, the interpretation of the trend for data obtained during any sample period in Apalachicola Bay is not simple, but depends on hydrodynamics which are influenced by Apalachicola River flow rate, wind speed and direction, and tidal current speed and direction (Huang \& Jones 1997). The nitrate concentration in St. George Sound water was always less than in Apalachicola River water (Figs. 4A, 6A, 8A, 10A). Therefore, water input from that source would be expected to affect the nitrate-salinity plot characteristics during months when water enters Apalachicola Bay from St. George Sound. This was the case during March (Fig. 5A) and during August (Fig. 9A) 1995, as indicated on the surface plots by arrows indicating water flow from St. George Sound into the estuary. Because nitrate concentrations in the estuary are affected by water exchange at multiple sources and by biological processes, it is not possible to calculate biological nitrate removal from nitrate-salinity plots within the estuary for those months from nitrate-salinity plots.

Property-salinity plots from a wide range of marine systems indicated that riverine DOM, which passed through estuaries and entered the sea was refractory (Georgia, USA, coastal waters, Gardner \& Stephens 1978; Severn Estuary and Bristol Channel UK, Mantoura \& Woodward 1983; and Zaire River estuary and plume, Cadée 1984). Considerable scatter was evident in a DON-salinity plot from the Laptev Sea, adjacent to the Lena River delta. However, a regression line for the data trend followed a dilution trend line expected for mixing Arctic surface water with Lena River delta water (Kattner et al. 1999), suggesting that DON was refractory or that biological processing of DON was occurring at very slow rates.
Meybeck (1993) computed global DON input from rivers to the ocean by multiplying DON concentration by flow rate for individual rivers where data were available. Our annual DON budget (Table 2) was prepared in a similar fashion, and indicates that the sum of river input and input from the passes is balanced by export from Apalachicola Bay to the GOM. However, DON concentrations within the estuary at some stations were greater than DON concentrations at the river or GOM end-member locations (Figs. 4B, 6B, 8B, 10B). DON export from the bay was greater than DON input to the bay during some months (Table 2). Therefore, DON must be produced within Apalachicola Bay as a result of various biogeochemical processes acting separately or in combination. The variability in DONsalinity plots is partly attributable to the effects of variable DON concentrations in waters entering the estuary from the river and the passes. This condition is most easily seen in data acquired during August 1995 (Figs. 9C \& 10B). For this month, DON concentrations at the western boundary were similar to Apalachicola River DON concentrations. DON concentrations at some locations in the estuary that were less than concentrations in the river and in St. George Sound represent the effects of dilution and, most likely, food-web processing. For example, in the Gulf of Riga, Baltic Sea, on average $13 \%$ of total DON was assimilated within 7 or $8 \mathrm{~d}$ by the bacterial community (Jørgensen et al. 1999). This was less than the 40 to $72 \%$ total DON assimilated measured in Delaware and Hudson River estuaries by Seitzinger \& Sanders (1997), and was attributed by Jørgensen et al. to a larger proportion of refractory organic matter and smaller amounts of anthropogenic compound input to the Gulf of Riga compared to the American estuaries.

Several processes may contribute to DON concentrations that frequently exceeded river and estuarine endmember DON concentrations in Apalachicola Bay (Figs. 4B, 6B, 8B, 10B). Photochemical release of nitrogen-containing compounds from DOM in coastal marine systems is a potential mechanism which may increase DON concentrations in estuarine surface waters (Bushaw et al. 1996). The experimental results of Bushaw-Newton \& Moran (1999), however, suggest that in southeastern US coastal waters between 1 and $2 \%$ of equivalent river DON concentrations are converted to ammonium and primary amines. In Apalachicola Bay, DON concentrations were at times between 117 to $144 \mathrm{mg} \mathrm{N} \mathrm{m}{ }^{-3}$ greater than the endmember DON concentrations (Fig. 6B). Therefore, mechanisms other than photochemical formation of DON from DOM must contribute to the high DON concentrations observed in this estuary.

Benthic DON flux may potentially contribute to the high DON concentrations observed in an estuarine 
water column. In the Parker River-Plum Island Sound estuary, located in Massachusetts, US, benthic DON fluxes were examined over an annual cycle (Hopkinson et al. 1999). With the exception of 1 occasion and at 1 station, however, DON was taken up and consumed by biochemical processes within the sediments (Hopkinson et al. 1999). Results of benthic nitrogen-flux studies in Chesapeake Bay also suggest that DON does not appear to be a major component of the nitrogen cycle (Cowan \& Boynton 1996, Burdige \& Zheng 1998). In Apalachicola Bay, surface DON concentrations were higher than benthic DON concentrations, except in April 1999 when bottom concentrations exceeded surface DON concentrations at locations that had salinities between 10 and 20 psu (Fig. 8B). Therefore, the DON concentration gradient in Apalachicola Bay does not indicate DON flux from the sediments as an important factor contributing to increased DON concentrations in the water column of that estuary.

Food-web processes, particularly those of phytoplankton, are important factors contributing to increased DON concentrations in estuarine waters. Collos (1992) demonstrated DIN uptake in excess of particulate nitrogen production, with DON export representing $75 \%$ of DIN uptake in early portions of unialgal batch-culture time-series. An inverse relation between nitrate and DON concentrations reported for the English Channel (Butler et al. 1979) and Chesapeake Bay (Bronk et al. 1998) suggests that phytoplankton DIN uptake was followed by DON release and accumulation in the water column. DON originating from phytoplankton can be released to the water column by excretion (Bronk \& Glibert 1993a, Pujo-Pay et al. 1997), cell death and lysis or virus-induced lysis (Suttle et al. 1990), or by 'sloppy feeding' of herbivores (Lampert 1978, Bronk \& Glibert 1993a, Hasegawa et al. 2000). This newly released DON, and a fraction of DON originating from river water, can be recycled by the microbial community (Wheeler \& Kirchman 1986, Bronk \& Glibert 1993b) and made available to primary producers.

\section{Nitrate and DON budgets}

Nutrient input to coastal plain estuaries has been estimated by adding diffuse and atmospheric input to the product of river flow-rate and nutrient concentration time-series, while export to seas bordering these estuary types has been estimated by subtracting internal losses from input rates (Kaul \& Froelich 1984, Boynton et al. 1995). This approach, however, does not provide valid results when applied to bar-built estuaries with multiple passes such as Apalachicola Bay. In Apalachicola Bay, input from the passes during both high- and low-river-flow conditions can account for a large fraction of the total nitrate or DON input to the estuary. In March and August 1995, for example, St. George Sound was a significant nitrogen source to the estuary. Nitrate and DON input through St. George Sound accounted for as much as 10 and $50 \%$, respectively, of the total dissolved nitrogen input to the estuary (Tables $1 \& 2$ ). Therefore, nutrient budget calculations for barbuilt estuaries require a combination of hydrodynamic modeling results and measurements of nutrient concentrations at river and pass locations.

There is a significant difference in transfer of nitrogen through estuaries with long residence-times compared to estuaries with short residence-times. Chesapeake Bay is a long (mean $=256 \mathrm{~d}$ ) residence-time estuary (Boynton et al. 1995). Approximately $30 \%$ of total nitrogen annually entering Chesapeake Bay is exported from the estuary (Boynton et al. 1995). However, there is net DON accumulation during the spring and net DON utilization during the summer-to-fall period in this estuary (Bronk et al. 1998). Therefore, in long residence time estuaries such as Chesapeake Bay, DON can serve as a nitrogen pool linking new nitrogen input from the river during the spring to a system based on regenerated productivity during the summer (Bronk et al. 1998).

Apalachicola Bay is a short (mean $=6 \mathrm{~d}$ ) residencetime estuary. This condition results in rapid passage of water and dissolved substances through that estuary. The annual budgets indicate that $66 \%$ of nitrate input was exported from the estuary, while DON input to and export from the estuary to the GOM were in balance (Mortazavi et al. 2000a). On a monthly basis, nitrate retention within the estuary varied between 0 and $100 \%$ of the input (Table 1). In contrast, DON retention within the estuary was not statistically significant during those months (Table 2). River DON and DON transformed from DIN entering the estuary was less likely to have remained within Apalachicola Bay to serve as a substrate for bacterial utilization and remineralization (Seitzinger \& Sanders 1997) than to be exported to the adjacent GOM. This was particularly true during March, a period when a seasonal phytoplankton bloom condition has been observed in GOM coastal waters by satellite imagery.

Nitrogen in water discharged from rivers along the Florida coast has been proposed as one of the alternate causal hypotheses for the recurring seasonal phytoplankton bloom in the northeastern GOM (Gilbes et al. 1996). The Apalachicola River dominates the freshwater discharge into the northeast GOM bloom region. Nitrate export from the estuary was $1821 \mathrm{t} \mathrm{N}$ during March 1995, while DON export was $993 \mathrm{t}$ during that month. Applying the conversion range of 40 to $70 \%$ experimentally obtained by Seitzinger \& Sanders (1997) to determine the fraction of DON that can be 
remineralized to DIN, from 397 to 695 t N were available for use by the northeastern GOM food web during that month. This calculation yields a total of 2218 to 2516 t $\mathrm{N}$ available for conversion to phytoplankton chlorophyll on the northeast GOM shelf during March 1995, a period when a bloom occurred off Apalachicola Bay (del Castillo et al. 2000).

Acknowledgements. This research was supported by a grant to R.L.I. and W. M. Landing from the Northwest Florida Water Management District and the Florida Department of Environmental Protection. Many thanks to C. Bailey, L. Edmiston and the staff of the Apalachicola National Estuarine Research Reserve for their assistance during sampling.

\section{LITERATURE CITED}

Berg GM, Glibert PM, Lomas MW, Burford MA (1997) Organic nitrogen uptake and growth by the chrysophyte Aureococcus anophagefferens during a brown tide event. Mar Biol 129:377-387

Bianchi TS, Pennock JR, Twilley RR (1999) Biogeochemistry of Gulf of Mexico estuaries: implications for management. In: Bianchi TS, Pennock JR, Twilley RR (eds) Biogeochemistry of Gulf of Mexico estuaries. John Wiley \& Sons, New York, p 407-421

Blumberg AF, Goodrich DM (1990) Modeling of windinduced destratification in Chesapeake Bay. Estuaries 13: 236-249

Blumberg AF, Herring J (1987) Circulation modeling using orthogonal curvilinear coordinates. In: Nihoul JCJ, Jamart BM (eds) Three dimensional models of marine and estuarine dynamics. Elsevier, Amsterdam, p 55-58

Blumberg AF, Mellor GL (1980) A coastal ocean numerical model. In: Sundermann J, Holz KP (eds) Mathematical modeling of estuarine physics, Proceedings of the International Symposium. Springer-Verlag, Berlin, p 203-214

Blumberg AF, Mellor GL (1987) A description of a threedimensional coastal ocean circulation model. In: Heaps NS (ed) Three-dimensional coastal models, Vol 4. American Geophysical Union, Washington, DC, p 1-16

Boyle E, Collier R, Dengler AT, Edmond JM, Ng AC, Stallard RF (1974) On the chemical mass-balance in estuaries. Geochim Cosmochim Acta 38:1719-1728

Boynton WR, Garber JH, Summers R, Kemp WM (1995) Inputs, transformation, and transport of nitrogen and phosphorus in Chesapeake Bay and selected tributaries. Estuaries 18:285-314

Braman RS, Hendrix SA (1989) Nanogram nitrite and nitrate determination in environmental and biological materials by vanadium (III) reduction with chemiluminescence detection. Anal Chem 61:2715-2718

Bronk DA, Glibert PM (1991) A ${ }^{15} \mathrm{~N}$ tracer method for the measurement of dissolved organic nitrogen release by phyoplankton. Mar Ecol Prog Ser 77:171-182

Bronk DA, Glibert PM (1993a) Contrasting patterns of dissolved organic nitrogen release by two size fractions of estuarine plankton during a period of rapid $\mathrm{NH}_{4}{ }^{+}$consumption and $\mathrm{NO}_{2}{ }^{-}$production. Mar Ecol Prog Ser 96: 291-299

Bronk DA, Glibert PM (1993b) Application of a ${ }^{15} \mathrm{~N}$ tracer method to the study of dissolved organic nitrogen uptake during spring and summer in Chesapeake Bay. Mar Biol 115:501-508
Bronk DA, Glibert PM, Malone TC, Banaham S, Sahlsten E (1998) Inorganic and organic nitrogen cycling in Chesapeake Bay: autotrophic versus heterotrophic processes and relationships to carbon flux. Aquat Microb Ecol 15:177-189

Burdige DJ, Zheng SL (1998) The biogeochemical cycling of dissolved organic nitrogen in estuarine sediments. Limnol Oceanogr 43:1796-1813

Bushaw KL, Zepp RG, Tarr MA, SchulzJander D, Bourbonniere RA, Hodson RE, Miller WL, Bronk DA, Moran MA (1996) Photochemical release of biologically available nitrogen from aquatic dissolved organic matter. Nature 381:404-407

Bushaw-Newton KL, Moran MA (1999) Photochemical formation of biologically available nitrogen from dissolved humic substances in coastal marine systems. Aquat Microb Ecol 18:285

Butler EI, Knox S, Liddicoat MI (1979) The relationship between inorganic and organic nutrients in sea-water. J Mar Biol Assoc UK 59:239-250

Cadée G (1984) Particulate and dissolved organic carbon and chlorophyll A in the Zaire River, estuary and plume. Neth J Sea Res 17:426-440

Collos Y (1992) Nitrogen budgets and dissolved organic matter cycling. Mar Ecol Prog Ser 90:201-206

Cowan JL, Boynton WR (1996) Sediment-water oxygen and nutrient exchanges along the longitudinal axis of Chesapeake Bay: seasonal patterns, controlling factors and ecological significance. Estuaries 19:562-580

Cox RD (1980) Determination of nitrate and nitrite at the parts per billion level by chemiluminescence. Anal Chem 52: 332-335

del Castillo CE, Gilbes F, Coble PG, Muller-Darger FE (2000) On the dispersal of riverine colored dissolved organic matter over the West Florida Shelf. Limnol Oceanogr 45: $1425-1432$

Eyre B, Balls P (1999) A comparative study of nutrient behavior along the salinity gradient of tropical and temperate estuaries. Estuaries 22:313-326

Frick EA, Buell GR, Hopkins EE (1996) Nutrient sources and analysis of nutrient water-quality data, ApalachicolaChattahoochee-Flint River basin, Georgia, Alabama, and Florida, 1972-90. United States Geological Survey, Atlanta, GA (Water-Resource Investigations Rep No. 96-4101)

Froelich P, Bender M, Luedtke N, Heath G, Devries T (1982) The marine phosphorus cycle. Am J Sci 282:474-511

Fu JM, Winchester JW (1994) Sources of nitrogen in three watersheds of northern Florida, USA: mainly atmospheric deposition. Geochim Cosmochim Acta 58:1581-1590

Galperin B, Mellor GL (1990) A time-dependent, 3-dimensional model of the Delaware Bay and River system. 2. 3dimensional flow-fields and residual circulation. Estuar Coast Shelf Sci 31:255-281

Galperin B, Kantha LH, Hassid S, Rosati A (1988) A quasiequilibrium turbulent energy model for geophysical flows. J Atmos Sci 45:55-62

Gardner WS, Stephens JA (1978) Stability and composition of terrestrially derived dissolved organic nitrogen in continental shelf surface waters. Mar Chem 6:335-342

Garside C (1982) A chemiluminescent technique for the determination of nanomolar concentration of nitrate and nitrite in seawater. Mar Chem 11:159-167

Gilbes F, Tomas C, Walsh JJ, Müller-Karger FE (1996) An episodic chlorophyll plume on the West Florida shelf. Cont Shelf Res 16:1201-1224

Hasegawa T, Koike I, Mukai H (2000) Dissolved organic nitrogen dynamics in coastal waters and the effect of copepods. J Exp Mar Biol Ecol 244:219-238 
Hopkinson CS, Giblin AE, Tucker J, Garritt RH (1999) Benthic metabolism and nutrient cycling along an estuarine salinity gradient. Estuaries 22:863-881

Howarth R (1988) Nutrient limitation of net primary production in marine ecosystems. Annu Rev Ecol Syst 19: $89-110$

Huang W, Jones WK (1997) Three-dimensional modeling of circulation and salinity for the low river flow season in Apalachicola Bay, FL. Northwest Florida Water Management District Water Resources, Havana, FL (Spec Rep No. 97-1)

Ittekkot V (1988) Global trends in the nature of organic matter in river suspensions. Nature 332:436-438

Jones WK, Huang W (1996) Modeling changing freshwater delivery to Apalachicola Bay, FL. In: Spaulding ML, Cheng RT (eds) Estuarine and coastal modeling: Proceedings of the 4th International Conference. American Society of Civil Engineering, New York, p 116-127

Jones WK, Galperin B, Weisberg RH, Wu TS (1994) Influence of Sikes Cut on Apalachicola Bay, FL: a preliminary analysis from a three-dimensional perspective. In: Spaulding ML, Bedford K, Blumberg A, Cheng RT, Swanson C (eds) Estuarine and coastal modeling: Proceedings of the 3rd International Conference American Society of Civil Engineering, New York, p 351-355

Jørgensen NOG, Tranvik LJ, Berg GM (1999) Occurrence and bacterial cycling of dissolved nitrogen in the Gulf of Riga, the Baltic Sea. Mar Ecol Prog Ser 191:1-18

Kattner G, Lobbes JM, Fitznar HP, Engbrodt R, Nothig EM, Lara RJ (1999) Tracing dissolved organic substances and nutrients from the Lena River through Laptev Sea (Arctic). Mar Chem 65:25-39

Kaul LW, Froelich PN (1984) Modeling estuarine geochemistry in a simple system. Geochim Cosmochim Acta 48: 1417-1433

Lampert W (1978) Release of dissolved organic carbon by grazing zooplankton. Limnol Oceanogr 23:831-834

Laroche J, Nuzzi R, Waters R, Wyman K, Falkowski PG, Wallace DWR (1997) Brown tide blooms in Long Island's coastal waters linked to interannual variability in groundwater flow. Glob Change Biol 3:397-410

Livingston RJ (1984) The ecology of the Apalachicola Bay system: an estuarine profile. US Fish and Wildlife Services, Washington, DC (FWS/OSB-82/05)

Loder TC, Reichard RP (1981) The dynamics of conservative mixing in estuaries. Estuaries 4:64-69

Mantoura RFC, Woodward EMS (1983) Conservative behavior of riverine dissolved organic-carbon in the Severn Estuary - chemical and geochemical implications. Geochim Cosmochim Acta 47:1293-1309

Mellor GL, Yamada T (1982) Development of a turbulence closure model for geophysical fluid problems. Rev Geophys 20:851-857

Meybeck M (1982) Carbon, nitrogen, and phosphorus transport by world rivers. Am J Sci 282:401-450

Meybeck M (1993) C, N, P and S in rivers: from sources to global inputs. Interactions of $\mathrm{C}, \mathrm{N}, \mathrm{P}$ and $\mathrm{S}$ biogeochemical cycles and global change. Springer-Verlag, Berlin, p 163-193

Mortazavi B, Iverson RL, Huang W, Lewis GF, Caffrey JM (2000a) Nitrogen budget of Apalachicola Bay: a bar-built estuary in the northeastern Gulf of Mexico. Mar Ecol Prog Ser 195:1-14

Mortazavi B, Iverson RL, Landing WM, Huang W, Lewis FG (2000b) Control of phytoplankton production and biomass

Editorial responsibility: Otto Kinne (Editor),

Oldendorf/Luhe, Germany in a river-dominated estuary: Apalachicola Bay, Florida, USA. Mar Ecol Prog Ser 198:19-31

Nixon SW (1995) Coastal marine eutrophication: a definition, social causes, and future concerns. Ophelia 41:199-219

Nixon SW, Granger SL, Nowicki BL (1995) An assessment of the annual mass balance for carbon, nitrogen, and phosophorus in Narragansett Bay. Biogeochemistry 31:15-61

NOAA (National Oceanic and Atmospheric Administration) (1997a) NOAA's estuarine eutrophication survey. Vol 2. Mid Atlantic region. NOAA, Silver Spring, MD

NOAA (National Oceanic and Atmospheric Administration) (1997b) NOAA's estuarine eutrophication survey. Vol 4. Gulf of Mexico region. NOAA, Silver Spring, MD

Officer CB (1979) Discussion on the behavior of nonconservative dissolved constituents in estuaries. Estuar Coast Mar Sci 9:91-94

Officer CB, Lynch DR (1981) Dynamics of mixing in estuaries. Estuar Coast Shelf Sci 12:525-533

Pennock JR, Boyer JN, Herrera-Silveira JA, Iverson RL, Whitledge TE, Mortazavi B, Comin FA (1999) Nutrient behavior and phytoplankton production in Gulf of Mexico estuaries. In: Bianchi TS, Pennock JR, Twilley RR (eds) Biogeochemistry of Gulf of Mexico estuaries. John Wiley \& Sons, New York, p 109-162

Pujo-Pay M, Raimbault P (1994) Improvement of the wet-oxidation procedure for simultaneous determination of particulate organic nitrogen and phosphorus collected on filters. Mar Ecol Prog Ser 105:1-2

Pujo-Pay M, Conan P, Raimbault P (1997) Excretion of dissolved organic nitrogen by phytoplankton assessed by wet oxidation and ${ }^{15} \mathrm{~N}$ procedures. Mar Ecol Prog Ser 153: 99-111

Regnier P, Mouchet A, Wollast R, Ronday F (1998) A discussion of methods for estimating residual fluxes in strong tidal estuaries. Cont Shelf Res 18:1543-1571

Seibold E, Berger WH (1993) The sea floor: an introduction to marine geology, 2nd edn., Springer-Verlag, Berlin

Seitzinger SP, Sanders RW (1997) Contribution of dissolved organic nitrogen from rivers to estuarine eutrophication. Mar Ecol Prog Ser 159:1-12

Sharp JH (1983) Nitrogen in estuaries and coastal marine environments. In: Carpenter EJ, Capone DG (eds) Nitrogen in the marine environment. Academic Press, New York, p 1-35

Strickland JD, Parsons TR (1972) A practical handbook of seawater analysis, 2nd edn. Bull Fish Res Board Can 167:1-310

Suttle CA, Chan AM, Cottrell MT (1990) Infection of phytoplankton by viruses and reduction of primary productivity. Nature 347:467-469

Tréguer P, Nelson DM, Van Bennekom AJ, DeMaster DJ, Leynaert A, Quéguiner B (1995) The silica balance in the world ocean: a reestimate. Science 268:375-379

van Beusekom JEE, de Jonge VN (1998) Retention of phosphorus and nitrogen in the Ems estuary. Estuaries 21: $527-539$

Wen LS, Shiller A, Santschi PH, Gill G (1999) Trace element behavior in the Gulf of Mexico Estuaries. In: Bianchi TS, Pennock JR, Twilley RR (eds) Biogeochemistry of Gulf of Mexico estuaries. John Wiley \& Sons, New York, p 303-346

Wheeler PA, Kirchman DL (1986) Utilization of inorganic and organic nitrogen by bacteria in marine systems. Limnol Oceanogr 31:998-1009

Yeats PA (1993) Input of metals to the North Atlantic from two large Canadian estuaries. Mar Chem 43:201-209

Submitted: June 20, 2000; Accepted: November 9, 2000

Proofs received from author(s): March 30, 2001 